\title{
The feasibility of regional food systems in metropolitan areas: An investigation of Philadelphia's foodshed
}

\author{
Peleg Kremer ${ }^{\mathrm{a}, *}$ \\ The New School \\ Yda Schreuder ${ }^{\mathrm{b}}$ \\ University of Delaware
}

Submitted 13 June 2011 / Accepted 3 November 2011 / Published online 10 February 2012

Citation: Kremer, P., \& Schreuder, Y. (2012). The feasibility of regional food systems in metropolitan areas: An investigation of Philadelphia's foodshed. Journal of Agriculture, Food Systems, and Community Development, 2(2), 171-191.

http://dx.doi.org/10.5304/jafscd.2012.022.005

Copyright (C) 2012 by New Leaf Associates, Inc.

\begin{abstract}
A rapidly globalizing food system raises important questions of environmental sustainability, food security, public health, and nutrition. The local food movement has been arguing for localization and regionalization of the food system as an effective strategy to counteract the risks of a globalized food system and promote sustainability.
\end{abstract}

${ }^{a}$ Center for Energy and Environmental Policy, University of Delaware.

Peleg Kremer is now at the Tishman Environment and Design Center, The New School

* Corresponding author: Peleg Kremer, Tishman Environment and Design Center, The New School, $725^{\text {th }}$ Avenue, New York, NY 10011 USA; +1-212-229-5100 ×3958; peleg.kremer@gmail.com

b Yda Schreuder, Professor, Department of Geography, and Senior Policy Fellow, Center for Energy and Environmental Policy, Department of Geography, University of Delaware, 216 Pearson Hall, Newark, DE 19716 USA; ydas@udel.edu
However, confusion abounds about what constitutes a local food system, and to date little evidence exists regarding the capacity of local food systems to support major metropolitan areas in the global North. This paper quantifies the ability of the Philadelphia region to support the dietary requirements of that city's population. Food production data for three foodshed scenarios in the Philadelphia region is analyzed and compared to the dietary requirements of the population based on federal dietary guidelines and current consumption patterns in the metropolitan region.

\section{Keywords}

local food systems, regional food systems, foodshed, Philadelphia

\section{Introduction}

In today's fast developing research on local and regional food systems, one enduring difficulty is the question of capacity of localities and regions to 
produce enough food to support their dietary requirements. It is often assumed that the capacity to feed urbanized regions in the developed world, and increasingly in the developing world, by utilizing resources within a region is a thing of the past. Still, the systematic study of local food systems is in its infancy, and in general, the feasibility of local food systems in terms of production capacity has not been the primary focus of food system studies (Martinez, S. W., Hand, M., Da Pra, M., Pollack, S., Ralston, K., Smith, T.,...Newman, C., 2010; Risku-Norja, Ketomaki, Hietala, Helenius, \& Virtanen, 2008). In a fundamental way, much like Berry (1990) suggests in his renowned quote that "eating is an agricultural act," the connection between what we eat and what we grow is (or at least ought to be) a direct one. However, the study and practice of agriculture, particularly in the United States, have been generally disconnected from the study of nutrition and dietary requirements (Peters, Fick, \& Wilkens, 2003).

In this study, we evaluate agricultural production in the agricultural hinterland of the Philadelphia food system. Three foodshed regions are defined and compared. These foodshed regions represent regions that emerged from previous research and the local food systems literature. A "current foodshed" includes 37 counties that were documented as currently supplying food to the local food system in the city. A " 50 -mile $(80.5 \mathrm{~km})$ foodshed" comprising 25 counties represents the average distance that farmers who supply local food markets travel to Philadelphia (Kremer, 2011; Kremer \& DeLiberty, 2011). Finally, a "100-mile (160.9 km) foodshed" comprising 69 counties represents the popular radius that is often used as a reference to local food systems in the literature (see for example Smith \& MacKinnon, 2008).

To contribute to the developing study of local and regional food systems, data on current agricultural production under these different definitions of foodshed regions are analyzed and compared to dietary requirements of the population based on the federal Dietary Guidelines for Americans (DGA) and current food consumption of four food groups: fruits, vegetables, meat, and dairy.

\section{Foodsheds, Regions, and the Question of Capacity}

An early attempt to make a connection between food production and dietary requirements used USDA food availability data to compare between actual consumption of food and federal dietary recommendations (Kantor, 1999). Although the stated purpose of the study was a time series evaluation of consumption patterns and the prediction of future dietary trends, the study appears to be the first to use the newly created 1995 loss-adjusted food availability dataset to evaluate the adequacy of food availability in the U.S. and its capacity to meet the dietary requirement of its population. The study concludes that food availability in the U.S. falls short of supplying federal dietary recommendations to the population in several important categories, including vegetables, fruit, dairy, and lean meats, while providing a large excess of added fats and sugars, a trend that is predicted to continue well into the future. Further breakdown of these categories into different types of fruits, vegetables, dairy products, and meats presented an even more perplexing picture, where the most nutritious foods were the least available. The study results were used to draw attention to deficits in the American diet, but could also be used to draw attention to deficits in farming practices that underlie food availability. In essence, these results indicate that American farms and agriculture policy fail to deliver the quality of foods needed for a balanced diet, and total caloric intake is often achieved through undesirable added fats and sugars.

In another chapter of the same publication, Young and Kantor (1999) offer a view of the types of changes American agriculture needs to make to supply an adequate diet to the U.S. population. They indicate that production of certain vegetables such as leafy greens, beans, and lentils would need to be increased by $200 \%$ to $300 \%$, while other foods, such as potatoes, would decrease by $30 \%$ to $40 \%$. Fruit production should increase by more than $100 \%$ and added fats and sugars decreased by $36 \%$ and $68 \%$, respectively. Calculating the overall required changes in agricultural land, the authors estimate that over 5 million acres (over 2 million 
hectars) would need to be added to production, mostly for fruits and vegetables, while other acres would need changes in their production patterns. While the study is highly aggregated, this approach sets the stage for a more refined understanding of the relationships between production and consumption of agricultural products in the U.S., an essential step for approaching the question of food systems as a question of sustainability. Addressing the direct connection between actual agricultural production and needed nutritional requirements opens new opportunities to set policies that encourage agricultural production for adequate nutrition (as defined by the DGA), such as promoting land use change toward producing nutritionally favorable crops (Peters et al., 2003; Young \& Kantor, 1999).

In a recent study, Peters, Wilkins, and Fick (2007) build on this approach and compare land use requirements for different diets and the availability of land to supply these requirements in New York State. They calculate the number of people who could be fed using the land resources in the state by constructing various dietary scenarios and find up to a fivefold difference between vegetarian and meat-based diets. The per capita land requirement to supply the different diets ranged between 0.45 acre per capita ( 0.18 ha per capita) for a vegetarian diet and 2.13 acres per capita ( 0.86 ha per capita) for a diet heavily based on meat. They concluded that with moderate meat consumption, the land base in New York state can feed about 21\% of the state's population. Additional research addressed a spatial conceptualization of localized food systems by estimating the potential for lowering the distance that food travels in New York state (Peters, Bills, Lembo, \& Wilkins, 2009). This study, comparing food production potential and food requirements in population centers in the state, used aggregations of agricultural potential and human dietary requirements and represented a major step forward in spatial analysis of local foodsheds. Its findings suggest that smaller urban centers in New York might be able to support their dietary requirements, using food produced locally, and that up to $98 \%$ of their food requirements could be produced within an average of 30.5 miles (49 km). However, as is often the case with large metropolitan regions, New York City is largely left out of this food system, with $2.2 \%$ of its food requirement potentially being met by local production with an average of 165 miles (265 km) traveled (Peters et al., 2009).

Using an average diet from the studies discussed above as a reference, the Delaware Valley Regional Planning Commission (DVRPC, 2010) chose an average of 1.23 acres ( 0.50 hectare) per capita to represent the amount of land required to supply an appropriate diet to the Philadelphia region population. They concluded that the DVRPC's ninecounty region can produce about $5 \%$ of its own food, and a 100-mile radius region around Philadelphia can produce about $11 \%$ of its food. However, when discussing a foodshed, a 100-miles radius is better understood as the production base for the DVRPC region. Viewed from this perspective, the region's capacity to provide the same diet just for Philadelphia residents is around 60\% (Clancy \& Ruhf, 2010).

The results of these studies reflect the limitations in understanding local food systems in major urban areas. One major issue when attempting to capture the concept of local food systems is the issue of scale and definition of a region. In the New York State study, the state is defined as the unit of analysis, although the state's foodshed may extend beyond the political boundaries of the state, and portions of the state may also be part of other regional foodsheds. Moreover, much confusion arises over the definition of a region for the purpose of foodshed analysis. In Philadelphia, for example, a 100-mile radius includes the population of both New York City and Baltimore in Philadelphia's foodshed, encompassing over 38 million people (or 13\% of the entire U.S. population). As figure 1 demonstrates, the designation of a 100mile radius around any large city is bound to overlap with foodsheds of other cities. New York City's 100-mile foodshed, for example, includes portions of New Jersey, Pennsylvania, Connecticut, and Massachusetts, and overlaps with the foodsheds of other large cities. In such cases, theoretical calculations of food production capacity fall short of the actual realities of food pathways. In fact, 


\section{Figure 1. Local Foodsheds Delineated by a 100 Mile Radius Around U.S. Cities with Population Larger than $\mathbf{5 0 , 0 0 0}$}

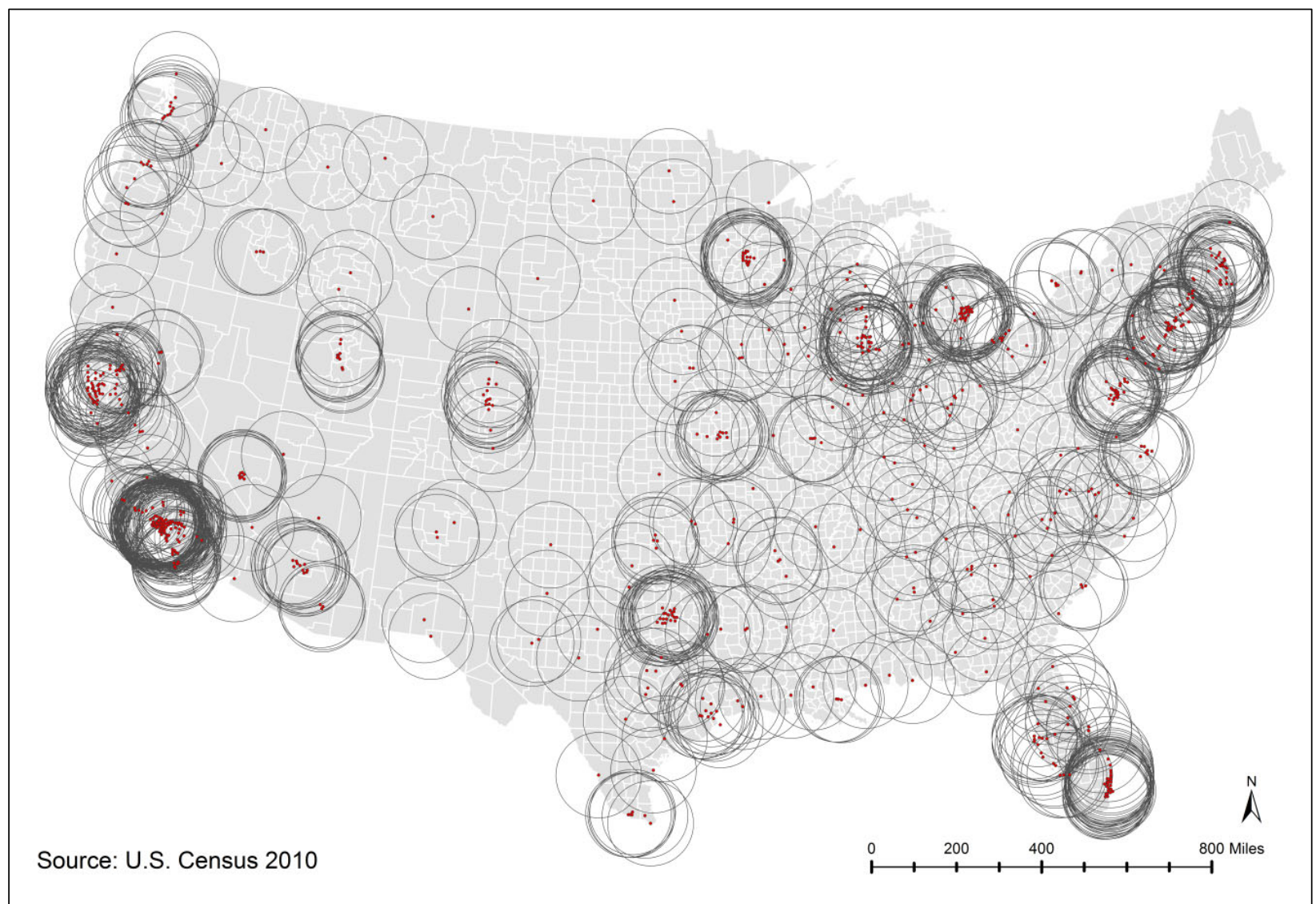

very few 100-mile circles around large cities do not overlap with other adjacent circles, and few of these circles are fully bound by the political boundaries of a single state. In addition, the geographic characteristics of a region do not always comply with the radius definition. In the case of Philadelphia, as in many other coastal cities, a significant portion of the 100-mile radius is occupied by the ocean. Of course, a 100-mile radius is used here as an arbitrary example for visualization, but the same exercise could be repeated using other radii.

Narrowing the analysis to the issue of food miles, as suggested by Peters et al. (2009), by exclusively optimizing the distance traveled by raw foods from the field to the adjacent population center, ignores a complicated reality of food systems infrastructure, such as processing capacity and distribution networks, and the economic reality that local food may travel toward higher-income areas. This situa- tion makes NYC a more likely recipient of food produced in that state than most other urban centers. Referring to the relationship between Pennsylvania and New Jersey agriculture and New York City markets, DVRPC (2010) cites this particular point as one of the barriers to widening the local food system in the Philadelphia region.

Another recent study that assesses the local food system potential in the Willamette Valley region in Oregon captures some of these complexities. Giombolini, Chambers, Schlegel and Dunne (2011) use state agricultural production data and USDA dietary recommendations to evaluate the capacity of that region to feed its own population. The region, as defined by the geography of the valley, comprises 10 counties and approximately 2.5 million people and is a major agricultural production region that caters to the largest cities in the state (Giombolini et al., 2011). Using current 
production data, they provide detail and insight into the different foods available in the region, thus enhancing the understanding of what is in fact possible locally. They find that for all the food groups, the valley does not produce enough food to support its population. Grain production was found sufficient to supply up to $73 \%$ of the dietary requirements, and dairy, up to $60 \%$. Vegetables and fruit presented a much grimmer picture, with $30 \%$ and $24 \%$, respectively. The authors also make the point that in reality $92 \%$ of wheat grain is exported to Asian markets, although they do not provide information about what portion wheat is of all grains, or about the actual destinations of any of the other crops.

In Finland, a study of the capacity and environmental impacts of localizing the food system in a rural area compared primary production capacity against a current diet and three constructed dietary scenarios that included 24 basic foods (Risku-Norja et al., 2008). The researchers found that while the region, a rural area with little population, was well capable of producing its own food, there were still major differences in food production capacity, depending on meat-based or vegetarian dietary choice. They also argue that both dietary choice and agricultural method can significantly influence the environmental impacts of the food system, suggesting that localization alone is insufficient to determine the full environmental impacts of the food system.

In sum, in the developing discussion about the capacity of localities and regions to supply their own food, the conclusion is often that selfsufficiency is rarely feasible, but that in principle, some capacity for self-sufficiency does exist. However, major questions remain regarding the definition of local and regional food systems and especially the capacity of different foodshed regions to feed major metropolitan areas. Building on the body of literature discussed so far and in order to further the study of local and regional food systems and foodsheds as they relate to large metropolitan areas, we define three foodshed regions around the city of Philadelphia and examine their capacity to produce the dietary require- ments of the city and the different foodshed regions.

\section{Philadelphia Metropolitan Region as a Foodshed}

A particularly difficult issue when evaluating a local food system is the ability to define the different components of the system (infrastructure, participants, types of food outlets, and food production), the system's physical extent, as well as its social and economic characteristics. Geographic definitions used in this paper are partly derived from an analysis of the Philadelphia local food system discussed elsewhere (Kremer et al., 2011; Kremer, DeLiberty, \& Schreuder, forthcoming) and supported by the literature on local food systems. In the analysis of the foodshed regions, the county is used as the unit of analysis, as it is the smallest scale for which detailed agriculture statistics are available. To explore how different definitions of the foodshed affect the capacity of the food system, a regional analysis was performed for the following three foodshed scenarios:

1. Current local foodshed: This region includes all counties that currently participate in the local food system in Philadelphia. They include farms that are sending their produce to farmers' markets, specialty stores, or other retail and institutional outlets in the city, or offer a CSA to city residents (Kremer, 2011; Kremer et al., 2011). It is the only foodshed that solely includes counties currently supplying local food to the city and the only one that is not spatially continuous. This foodshed includes 37 counties.

2. 50 -mile $(80.5 \mathrm{~km})$ foodshed: This region represents the average distance currently traveled by farmers supplying local food markets to the city (Kremer et al., 2011) and is the smallest foodshed, of 25 counties.

3. 100-mile $(160.9 \mathrm{~km})$ foodshed: A radius widely used in the discussion of local food systems and one of the most popular icons for the local food movement. This foodshed includes 69 counties. 
Counties from five states, Pennsylvania, New Jersey, Delaware, Maryland, and New York, are represented in different combinations in this analysis. County demographic data was retrieved from the 2000 Census, and agriculture data was acquired using the USDA Census of

Agriculture 2007 Desktop Dataquery Tool (USDA-NASS, 2007). The participating counties in each of the defined foodshed regions are mapped in figure 2 , and the population density within each foodshed region is presented alongside per capita sales of agricultural products. Table 1 summarizes the key population and agricultural land-use characteristics of the three foodshed regions.

As shown in Table 1, the population in

\section{Figure 2. Three Defined Foodshed Regions}

On the left: Population density in the study area. On the right: Per capita sales of agricultural products.

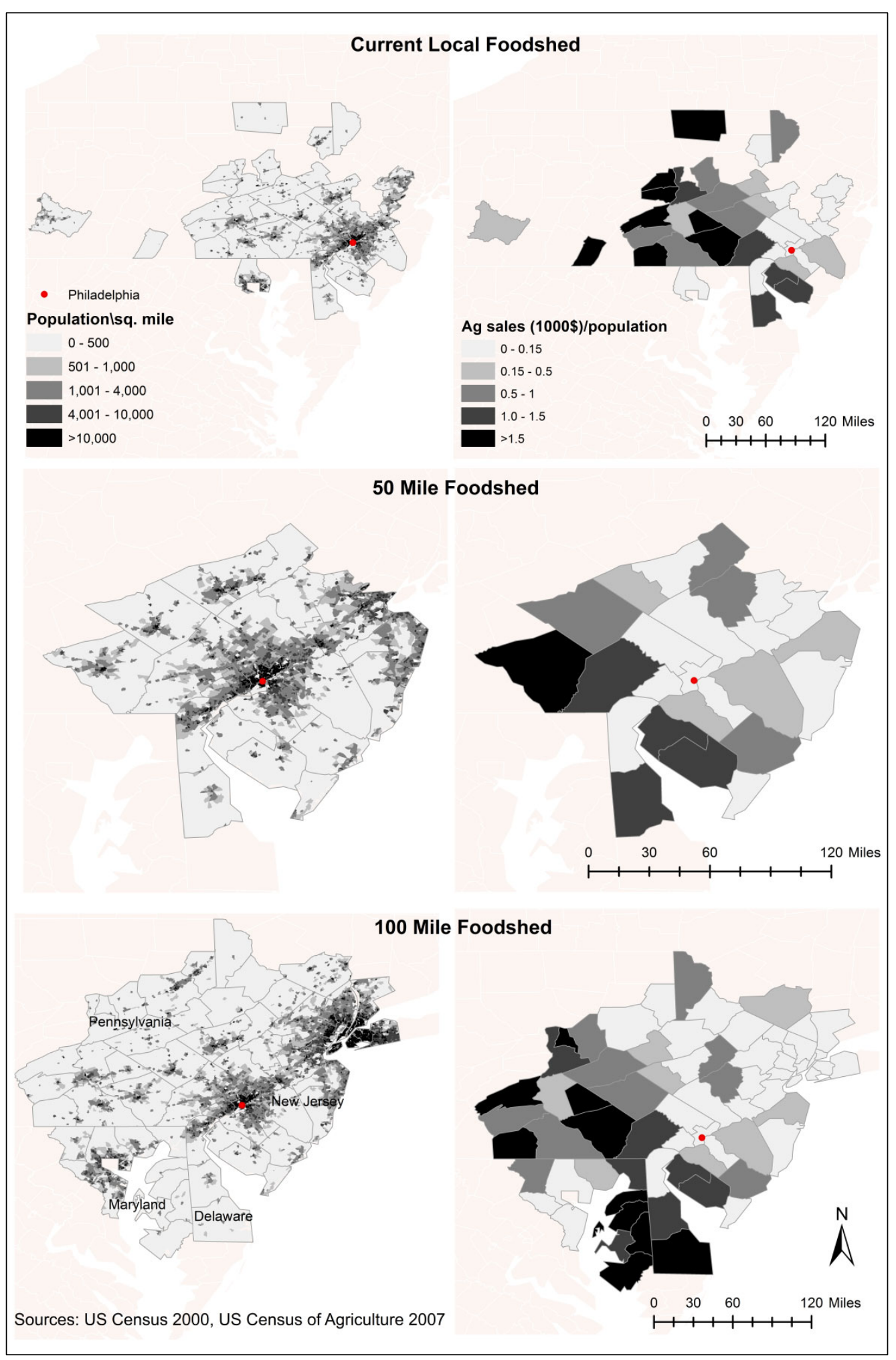


Philadelphia represents a small portion of the total population of the region under all foodshed definitions, its portion ranging from $14 \%$ in the case of the 50-mile foodshed to $5 \%$ in the case of the 100-mile foodshed (which itself contains about $10 \%$ of the total U.S. population). While the focus of this analysis is on the foodsheds' capacity to feed Philadelphia, the fact that the city is part of the most densely populated region in the United States and has an immediate proximity to other significant metropolitan areas, such as New York and Baltimore, introduces complications and subtleties to the regional analysis that require further attention and will be discussed in some detail later in this paper.

Some counties within the region, such as Philadelphia itself, New York City, and Ocean County, New Jersey, have little agricultural production reflected in the USDA statistics. However, most counties do have major agricultural output, and some are even primarily agriculture counties, such as Lancaster and Berks counties in Pennsylvania and Sussex County in Delaware. Figure 3 presents the distribution of sales for all agricultural product groups in the three defined foodshed regions. Figure 4 displays agricultural products sales by major agriculture food groups (produce, grains, meat, poultry, and dairy). In general terms, closer to the coast where population density is usually higher, agricultural production tends to be mixed and includes a higher percentage of fruits, vegetables, and nursery crops. As population density drops (to the west in Pennsylvania and the south in Delaware), agricultural production concentrates on grain, milk, and livestock. Overall, the region is characterized by relatively small farm size, with the average in most counties being smaller than 100 acres (40 hectares).

\section{Methodology}

The methodology used in this paper builds on previous studies that compared food production (Giombolini et al., 2011; Kantor, 1999; RiskuNorja et al., 2008), or potential food production (Peters, Wilkens, \& Fick, 2007) to dietary requirements of a defined population. Here, we chose to use the current agricultural production in the designated region as the basis for analysis because it enables a more realistic and specified picture of the regional current situation and may be more indicative of the types of changes necessary to build a successful localized food system. While other studies adopted a similar approach (see Giombolini et al., 2011; Risku-Norja et al., 2008), our study reflects a more complicated situation,

Table 1. Summary of Land Use and Agricultural Production in Three Foodshed Regions

\begin{tabular}{|c|c|c|c|}
\hline Variable & Current Foodshed & 50 mile & 100 mile \\
\hline Population & $12,058,140$ & $11,049,429$ & $31,211,500$ \\
\hline Philadelphia city population share of region (\%) & $13 \%$ & $14 \%$ & $5 \%$ \\
\hline Agriculture acres per person & 0.26 & 0.15 & 0.13 \\
\hline Agriculture acres per Philadelphia person & 2.06 & 1.06 & 2.70 \\
\hline \multicolumn{4}{|l|}{ Agriculture land use (acres, 2007) } \\
\hline Crop-pasture or grazing & 162,473 & 78,775 & 193,936 \\
\hline Crop-harvested cropland & $2,468,727$ & $1,325,689$ & $3,333,042$ \\
\hline Crop- other cropland & 222,472 & 73,123 & 256,460 \\
\hline Permanent pasture and rangeland & 297,235 & 142,803 & 342,399 \\
\hline Woodland not pastured & 552,369 & 203,546 & 698,848 \\
\hline Woodland pastured & 42,331 & 17,760 & 48,338 \\
\hline Total land in agriculture & $3,193,238$ & $1,638,150$ & $4,174,175$ \\
\hline
\end{tabular}

Compiled from 2007 Census of Agriculture (USDA-NASS, 2007; USDA, 2007), 2000 Census of Population (U.S. Census Bureau, 2000) 
Figure 3. Agricultural Production Sales (in US\$1,000) by Region and Product Group

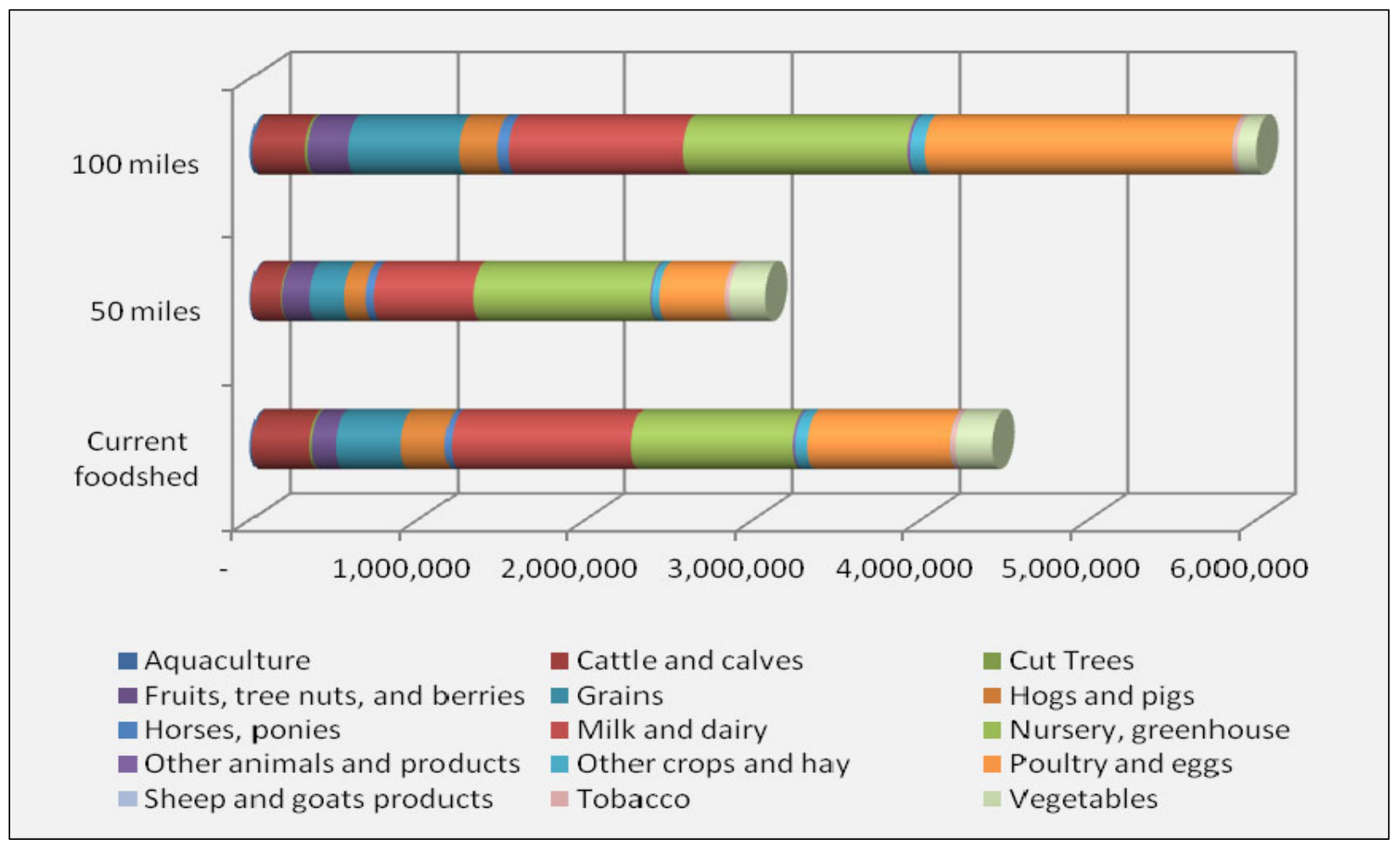

namely that of a metropolitan area. The major challenge in constructing a regional analysis for this study is in integrating scarce and fragmented data of county agriculture land use into a model that can calculate estimated agriculture yields for different foods and then categorize them into USDA nutrition guidelines food groups. This methodology covers most food groups: vegetables, fruit, poultry and eggs, and meat and dairy. However, it was not feasible to determine the amount of crops in the region used for the production of oils. It is reasonable to assume that a portion of the corn and soy production in the region is used for oils; however, we had no reliable way to estimate this portion or the amount of oils produced from those crops. Other oil crops are not grown in significant quantity in the region. For this reason, the food group of oils was not included in our analysis.

\section{Agricultural Production}

The baseline agriculture data was acquired from the 2007 census of agriculture for each of the counties using the USDA Census of Agriculture 2007 Desktop Dataquery Tool (USDA-NASS, 2007). With this tool, all counties were selected for each data point. All data was queried and aggregated into tables of data points by county within the relevant foodshed. Using ESRI ArcGIS 10, geographic attributes of census county data were joined to tables containing agriculture census data, enabling the spatial representation of the agriculture statistics.

Within the food groups, data appeared in different formats for different foods. Fruit and vegetable data was available only as the number of cultivated acres per county. This data was then multiplied by national average yield, in pounds per acre, calculated from total production and cultivated acres published in the most recently available Vegetables and Melons Yearbook (USDA-ERS, 2009b) and the Fruit and Tree Nut Yearbook (USDA-ERS, 2009a) published annually by USDA Economic Research Service. To most accurately fit the regional data available, yields for 2007 are used. 
Figure 4. Agriculture Sales in Three Foodshed Regions by Product Group

Maps represent percent of total sales for each agricultural product group within each county.

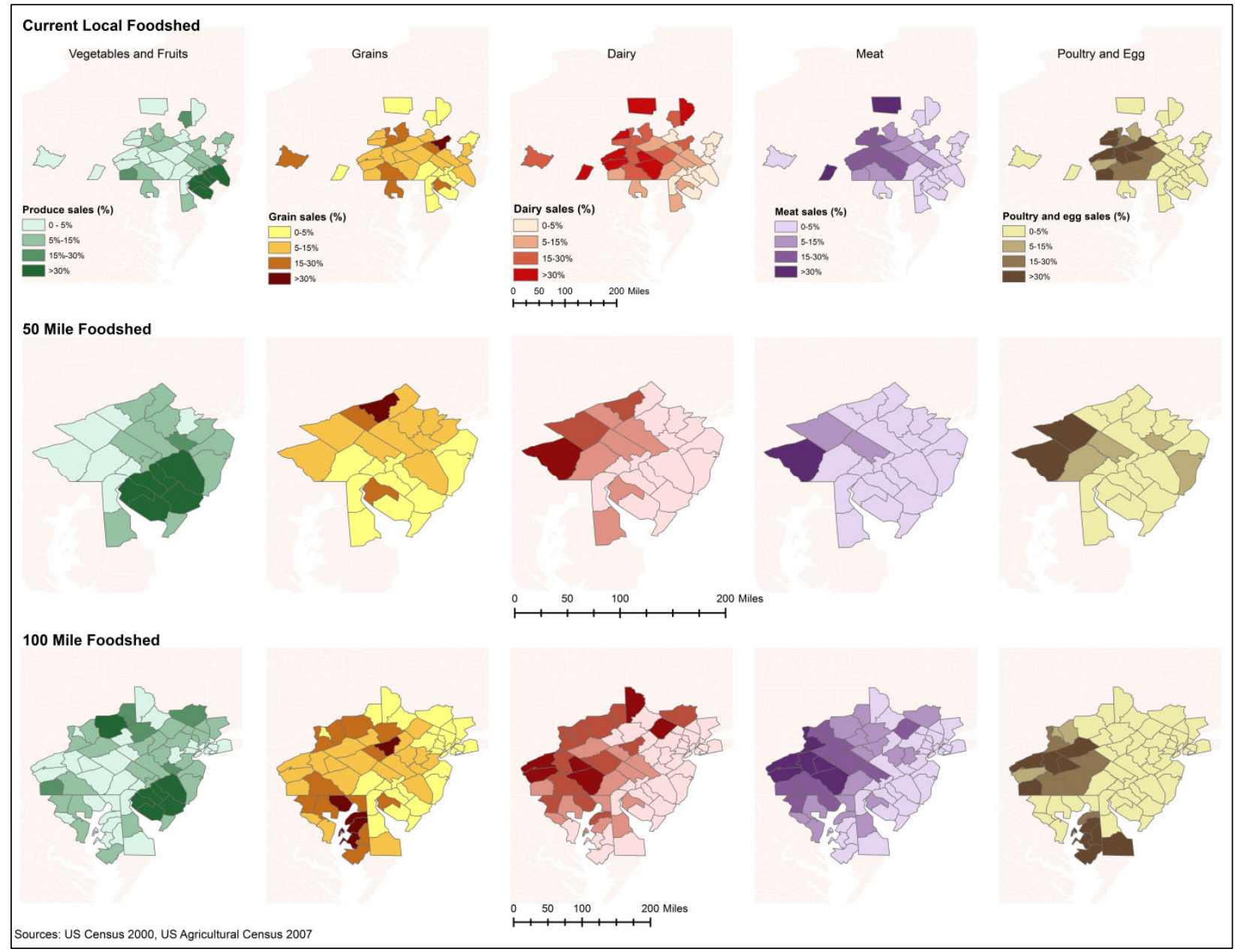

Grain data was available in the form of production of bushel per acre and converted to pounds of relevant commodities such as wheat flour and cornmeal. Meat and poultry data is available as the number of animals sold for slaughter in each county. These number were converted to pounds of meat using the national Livestock Slaughter, and Poultry-Production and Value, annual reports (USDA-NASS, 2009a; USDA-NASS, 2009b). Milk production data was available as the number of milk cows residing in each county. Statistics of milk production are collected continuously by USDA from a sample of 23 states across the country (personal email correspondence with Roger Hoskin of USDA-ERS, June 25, 2010). In this case, average milk production per cow was based on 11 counties that are included in the region of this study and are part of the national sample was used to calculate milk production. Data about egg production was available as the number of dozens of eggs produced in 2007.

\section{Dietary Requirements}

To estimate the dietary requirements for the population of the city of Philadelphia and the foodshed regions, federal Dietary Guidelines for Americans (DGA) are employed (USDA \& USDHHS, 2010). Dietary guidelines are represented by six food groups: fruit, vegetables, grains, dairy, protein foods, and oils. Further recommendations within these groups exist, such as the classification of vegetables into groups that distinguish between 
green, leafy, and starchy vegetables, but for simplification here, we addressed only the above mentioned groups. Table 2 presents the dietary recommendations for different age groups by gender. The DGA are also divided by a recommended calorie intake for each age-gender group, and the amount recommended is then represented by standardized units of consumption - cups, ounce equivalents, or grams.

Similarly to Giombolini et al. (2011), this study uses dietary guidelines for moderately active persons, as data on the activity levels of the population in the study area is limited. Moderate activity represents an average level of activity that lies between sedentary and highly active persons. Using population data from the 2000 Census, grouped by age according to the divisions in the dietary guidelines, enabled the calculation of total dietary requirements, by food group, for the study population.

An additional parameter often used to estimate average food consumption in the U.S. is the USDA's Economic Research Service Per Capita Food Availability dataset (USDA-ERS, n.d.). This dataset estimates the availability of specific food products by calculating total production, imports, and exports normalized for the population. The data is often used as a proxy for current food consumption trends in the population and is used here as a comparative indicator for the capacity of the food system. Average annual per capita consumption of food by food group is summarized in Table 4.

\section{Results}

\section{Dietary Requirements of Philadelphia and the Foodshed Populations}

Dietary requirements of the Philadelphia population were calculated using the DGA (USDA \& USDHSS, 2010). DGA differ by age group, gender and activity level. It was not possible to delineate population groups by activity level for this research, so the dietary guidelines for moderately active persons, and an average activity level, were used for all population groups. Population data was acquired from the 2000 Census of Population (U.S. Census Bureau, 2000). Data was downloaded for all ages (0-110) for Philadelphia as well as all the

Table 2. Dietary Guidelines by Age and Gender for Moderately Active Persons by Food Group (daily consumption)

\begin{tabular}{|c|c|c|c|c|c|c|c|c|}
\hline Gender & Age & $\begin{array}{l}\text { Moderately Active } \\
\text { Calories }\end{array}$ & Fruits (cups) & $\begin{array}{l}\text { Vegetables } \\
\quad \text { (cups) }\end{array}$ & Grains (oz eq) & $\begin{array}{l}\text { Lean Meat } \\
\text { and Beans } \\
\text { (oz eq) }\end{array}$ & Dairy (cups) & Oils (g) \\
\hline Children & $2-3$ & $1,000-1,400$ & 1.50 & 1.50 & 5.00 & 4.00 & 2.50 & 7 \\
\hline \multirow[t]{6}{*}{ Female } & $4-8$ & $1,400-1,600$ & 1.50 & 2.00 & 5.00 & 5.00 & 3.00 & 2 \\
\hline & $9-13$ & $1,600-2,000$ & 2.00 & 2.50 & 6.00 & 5.50 & 3.00 & 7 \\
\hline & $14-18$ & 2,000 & 2.00 & 2.50 & 6.00 & 5.50 & 3.00 & 7 \\
\hline & $19-30$ & $2,000-2,200$ & 2.00 & 3.00 & 7.00 & 6.00 & 3.00 & 9 \\
\hline & $31-50$ & 2,000 & 2.00 & 2.50 & 6.00 & 5.50 & 3.00 & 7 \\
\hline & $51+$ & 1,800 & 1.50 & 2.50 & 6.00 & 5.00 & 3.00 & 4 \\
\hline \multirow[t]{6}{*}{ Male } & $4-8$ & $1,400-1600$ & 1.50 & 2.00 & 5.00 & 5.00 & 3.00 & 2 \\
\hline & $9-13$ & $1,800-2,200$ & 2.00 & 3.00 & 7.00 & 6.00 & 3.00 & 9 \\
\hline & $14-18$ & $2,400-2,800$ & 2.50 & 3.50 & 10.00 & 7.00 & 3.00 & 6 \\
\hline & $19-30$ & $2,600-2,800$ & 2.50 & 3.50 & 10.00 & 7.00 & 3.00 & 6 \\
\hline & $31-50$ & $2,400-2,600$ & 2.00 & 3.50 & 9.00 & 6.50 & 3.00 & 4 \\
\hline & $51+$ & $2,200-2,400$ & 2.00 & 3.00 & 8.00 & 6.50 & 3.00 & 1 \\
\hline
\end{tabular}

Compiled from: Dietary Guidelines for Americans 2010 (USDA \& USDHHS, 2010) 
Journal of Agriculture, Food Systems, and Community Development

ISSN: 2152-0801 online

www.AgDevJournal.com

Table 3. Total Food Requirements of the Philadelphia Population by Age Group According to the DGA

\begin{tabular}{|c|c|c|c|c|c|c|c|c|}
\hline Gender & Age (years) & Calories 1 & Fruits 2 & Vegetables 2 & Grains (ton) & Meat2 & Milk ${ }^{3}$ & Oils (ton) \\
\hline Child & $2-3$ & $1000-1400$ & 21.68 & 21.68 & $1,024.46$ & 28.91 & 14.45 & 122.87 \\
\hline \multirow[t]{6}{*}{ Female } & $4-8$ & $1400-1600$ & 58.67 & 78.22 & $2,771.96$ & 97.78 & 58.67 & 430.22 \\
\hline & $9-13$ & $1,600-2,000$ & 82.61 & 103.26 & $3,512.86$ & 113.59 & 61.96 & 557.61 \\
\hline & $14-18$ & 2000 & 76.91 & 96.14 & $3,270.54$ & 105.75 & 57.68 & 519.14 \\
\hline & $19-30$ & $2,000-2,200$ & 216.20 & 324.31 & $10,726.25$ & 324.31 & 162.15 & $1,567.48$ \\
\hline & $31-50$ & 2000 & 326.30 & 407.87 & $13,875.66$ & 448.66 & 244.72 & $2,202.52$ \\
\hline & $51+$ & 1800 & 262.71 & 437.84 & $14,895.17$ & 437.84 & 262.71 & $2,101.65$ \\
\hline \multirow[t]{6}{*}{ Male } & $4-8$ & $1400-1600$ & 60.56 & 80.74 & $2,861.21$ & 100.93 & 60.56 & 444.08 \\
\hline & $9-13$ & $1,800-2,200$ & 85.35 & 128.02 & $4,234.29$ & 128.02 & 64.01 & 618.78 \\
\hline & $14-18$ & $2,400-2,800$ & 96.56 & 135.19 & $5,475.01$ & 135.19 & 57.94 & 695.25 \\
\hline & $19-30$ & $2,600-2,800$ & 245.59 & 343.82 & $13,924.53$ & 343.82 & 147.35 & $1,768.22$ \\
\hline & $31-50$ & $2,400-2,600$ & 290.08 & 507.64 & $18,503.17$ & 471.38 & 217.56 & $2,465.68$ \\
\hline & $51+$ & $2,200-2,400$ & 241.62 & 362.43 & $13,699.53$ & 392.63 & 181.21 & $1,872.54$ \\
\hline
\end{tabular}

1 Number of daily calories recommended for Moderately Active persons; 2 million servings; 3 million cups

\section{Table 4. Food Availability by Food Group (annual kg/capita)}

\begin{tabular}{|c|c|}
\hline Food Group & $\begin{array}{l}\text { Average Consumption } \\
(2007, \mathrm{~kg} / \text { capita })\end{array}$ \\
\hline Vegetables & 124.9 \\
\hline Fruit & 118.2 \\
\hline Milk and Dairy & 121.0 \\
\hline Grains & 89.5 \\
\hline Poultry and eggs & 48.0 \\
\hline Meat & 91.1 \\
\hline
\end{tabular}

Compiled from: USDA Economic Research Service- Food Availability (Per Capita) Data System (USDA-ERS, n.d.)

counties in the three defined foodshed regions. Population was then grouped into age groups corresponding to the gender and age groups used in the dietary guidelines. Babies under two years are not included in the calculations because they are not included in the dietary guidelines. All children between 2 and 3 years old are grouped together because the guidelines are gender neutral at this age group. The rest of the age groups, 4-8, 9-13,1418, 19-30, 31-50, and 51 and over, are aggregated by gender.
The DGA, as presented in Table 2, suggest the number of servings necessary for appropriate nourishment from each food group. Servings are an abstract unit that may contain differing quantities in different foods. For example, one serving of fruits or vegetables is measured as half a cup, which can mean 28 grams of lettuce, 50 grams of cauliflower, 90 grams of tomato, and so on. One serving of dairy is equivalent to one cup (244 grams) of milk, and one serving of meat is equivalent to one ounce (28 grams). An egg, for example, is considered equivalent to one ounce of meat and one serving in the meat, poultry, and eggs group. The calculations in this study are based on the number of servings required by the population for each food group. Daily recommended servings are multiplied by the number of persons in the corresponding age-gender group and then converted to annual consumption. The result is the total annual number of servings required to feed the different population groups. Table 3 summarizes the amount of servings required to appropriately feed the population of Philadelphia by gender and age group for each food group, assuming a moderately active lifestyle. Table 5 summarizes the number of servings required to appropriately feed the entire population within each defined foodshed region. 
Table 5. Total Food Requirements in Philadelphia and the Three Foodshed Regions According to the DGA

\begin{tabular}{lcccccc}
\hline Foodshed Region & Fruits $^{1}$ & Vegetables $^{1}$ & Grains (ton) & Meat $^{1}$ & Milk $^{2}$ & Oils (ton) \\
\hline Philadelphia & 2,0645 & 3,027 & 108,775 & 3,129 & 1,591 & 15,366 \\
\hline Current foodshed & 15,119 & 22,159 & 801,352 & 22,983 & 11,572 & 112,834 \\
\hline 50 mile & 14,381 & 21,063 & 761,7667 & 21,850 & 11,001 & 107,272 \\
\hline 100 mile & 41,156 & 60,277 & $2,181,361$ & 62,493 & 31,416 & 306,932 \\
\hline
\end{tabular}

1 million servings; 2 million cups

Table 6. Food Consumption in Philadelphia and Three Foodshed Regions According to ERS Food Availability Data

\begin{tabular}{lccccc}
\hline Foodshed Region & Fruits (ton) & Vegetables (ton) & Grains (ton) & $\begin{array}{c}\text { Meat, Poultry } \\
\text { and Eggs (ton) }\end{array}$ & Dairy (ton) \\
\hline Philadelphia & 172,460 & 182,353 & 130,678 & 202,968 & 176,592 \\
\hline Current foodshed & $1,259,427$ & $1,331,674$ & 954,303 & $1,482,216$ & $1,289,603$ \\
\hline 50 mile & $1,197,710$ & $1,266,416$ & 907,538 & $1,409,580$ & $1,226,407$ \\
\hline 100 mile & $3,420,652$ & $3,616,876$ & $2,591,923$ & $4,025,753$ & $3,502,611$ \\
\hline
\end{tabular}

The second method applied here to estimate the food requirements of a population is based on food availability data collected by the Economic Research Service of USDA (USDA-ERS, n.d.). This data, an average estimate of the total food available to a population, is widely used as a proxy for food consumption by the population. The data represents the types of food that people actually eat rather than what is considered good for them to eat (per the DGA). We use this data, grouped to match the food groups in the DGA, as a comparative measure of the region's capacity to supply its food requirements. We use average annual consumption of food in the different groups, as presented in Table 4, multiplied by the population in the city and the three defined foodshed regions. The method used to derive this dataset does not allow for age and gender specification, and thus the results represent an overall average of current consumption. Table 6 presents the total food consumption in the different food groups calculated using this method.

\section{Food Requirements for Animal Feed}

Since meat and dairy make up significant parts of food consumption in the United States, calculating a population's dietary requirements needs to
Table 7. Feed Grain Requirements for Philadelphia and Three Foodshed Regions

\begin{tabular}{lc}
\hline Foodshed Region & Feed grain required (ton) \\
\hline Philadelphia & 379,560 \\
\hline Current foodshed & $14,445,213$ \\
\hline 50 mile & $7,472,399$ \\
\hline 100 mile & $17,529,073$ \\
\hline
\end{tabular}

account for the food necessary to feed the animals that provide milk, eggs, and meat. To include the food requirements of animals that provide milk, eggs, and meat to the population of the region and avoid overcounting grain production for human food products, grains were divided into two groups: grains used directly for human consumption and grains used as animal feed. This way it is possible to estimate the region's capacity to provide animal feed as well as food for direct human consumption. It is difficult to estimate food requirements of animals because they vary greatly with geography and production methods. Here, we used consumption factors calculated as U.S. average grain consumption per kilogram of meat production for the different products: beef, pork, eggs, milk, broilers, and turkeys (Pimentel \& 
Pimentel, 2008). Total production for each of these groups is multiplied by the consumption factors.

The total grain requirements presumed needed for animal feed are summarized in table 7 .

\section{Food Production in the Foodshed}

Total regional food production is presented here for all the food groups and foodshed regions as defined above. In term of sales, as presented in Figure 3, the largest food sectors are poultry, eggs, and dairy, while in terms of actual production, grains are by far the largest crop of the region, followed by dairy. Meat, poultry, and eggs represent the third largest food group in all the defined foodshed regions except for the 50-mile foodshed, where vegetable production is greater. A comparison of food production by food group and foodshed region is presented in Figure 5.

For the purpose of comparing food production and food requirements, the calculated food production dataset was converted into units of food requirements. For the federal dietary guidelines, food production was converted into units of servings (vegetables, fruits, and meat), cups (milk), and grams (grains). Serving sizes and weights of different foods are based on data available from the USDA and in the literature (Giombolini et al., 2011; Kantor, 1998; USDAERS, n.d.; USDA-FNS, 2009). Table 8 summarizes the total food production for the defined foodshed regions.

\section{Comparing Food Requirements and Food Production} Having estimated the production of food in the defined foodshed regions and the food requirements in the city and the foodshed regions, it is now possible to compare them. However, the comparison will not indicate the current reality because little regional food production can be currently attributed to local food consumption. Nonetheless, the analysis sheds light on the

\section{Figure 5. Food Production by Food Group}

The proportion of food produced in each food group for three foodshed regions. Percentages based on production (in tons) out of total production in each foodshed. Numbers inside the bars represent actual production in 1,000 tons.

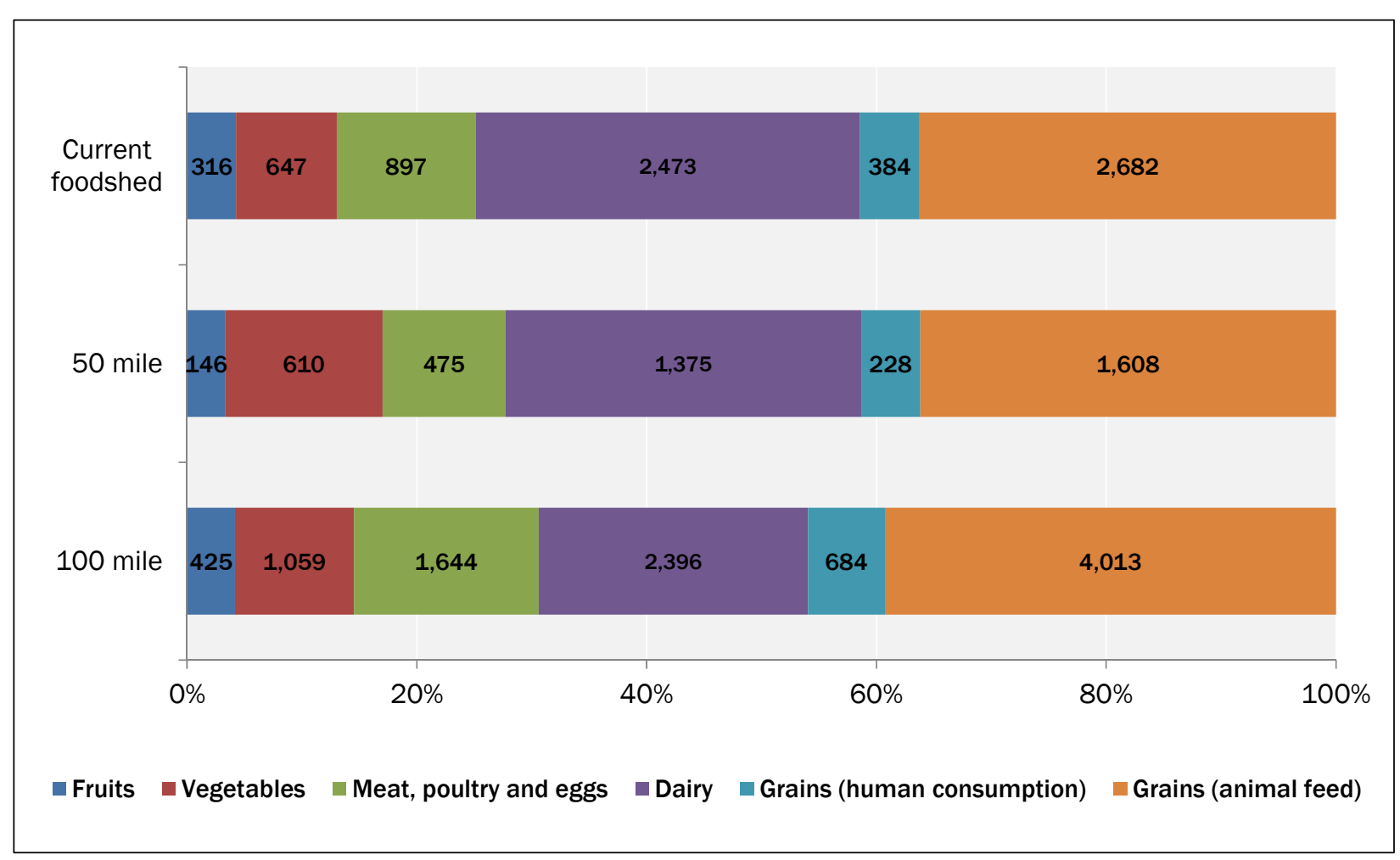


Table 8. Food Production Converted to DGA Units in Three Foodshed Regions

\begin{tabular}{|c|c|c|c|c|c|}
\hline Foodshed region & Fruits ${ }^{1}$ & Vegetables $^{1}$ & Grains (ton) & Meat ${ }^{1}$ & Milk $^{2}$ \\
\hline Current foodshed & 2,634 & 9,080 & 383,930 & 31,598 & 10,126 \\
\hline 50 mile & 1,476 & 8,780 & 228,071 & 16,723 & 5,632 \\
\hline 100 mile & 3,925 & 14,595 & 683,415 & 57,945 & 9,811 \\
\hline
\end{tabular}

1 million servings; 2 million cups

Table 9. Proportion of Food Produced in the Three Foodsheds That Is Consumed by Philadelphia*

\begin{tabular}{lccccc}
\hline Foodshed region & Fruits & Vegetables & Grains & Meat & Milk \\
\hline Current foodshed & $78 \%$ & $33 \%$ & $28 \%$ & $10 \%$ & $16 \%$ \\
\hline 50 mile & $140 \%$ & $34 \%$ & $48 \%$ & $19 \%$ & $28 \%$ \\
\hline 100 mile & $53 \%$ & $21 \%$ & $16 \%$ & $5 \%$ & $16 \%$ \\
\hline
\end{tabular}

* Calculated as Philadelphia's total food requirements for each food group divided by total production for each food group within each foodshed region

Table 10. Proportion of Produced Food Consumed by Each Foodhsed's Entire Population*

\begin{tabular}{lccccc}
\hline Foodshed region & Fruits & Vegetables & Grains & Meat Eaten & Milk \\
\hline Current foodshed & $574 \%$ & $244 \%$ & $209 \%$ & $73 \%$ & $114 \%$ \\
\hline 50 miles & $975 \%$ & $240 \%$ & $334 \%$ & $131 \%$ & $195 \%$ \\
\hline 100 miles & $1048 \%$ & $413 \%$ & $319 \%$ & $108 \%$ & $320 \%$ \\
\hline
\end{tabular}

* Calculated as total food requirements of the population in all counties included in each foodshed region for all food groups, divided by total production in each food group within each foodshed region

potential and capacity in the region to produce food and can be used to focus attention on barriers and opportunities for the development of a more localized food system.

Using the calculated datasets of production and requirements, we first evaluate how much of the regional food production under the different foodshed definitions would be consumed by Philadelphia's population based on the DGA. Second, we calculate the capacity of the different regions to supply the dietary requirements of their full populations. Table 9 and 10 summarize the capacity of the three foodshed regions to support Philadelphia's food requirements and the selfsufficiency capacity of the foodshed regions. Percentages in the tables represent the portion of produced food that would be consumed by the defined population. Hence, any number under $100 \%$ represents sufficient capacity to feed the population, while numbers above $100 \%$ represent a deficiency. This two-step calculation was then repeated using estimated actual food consumption data based on the USDA ERS food availability dataset to compare the findings of the foodshed capacity based on the dietary guidelines to a foodshed capacity based on current consumption patterns. Figure 6 visualizes these results by representing the ratio between food production and food requirements, by food group, as either a shortage or surplus of food, first for Philadelphia and then for all foodshed regions. Figure 7 illustrates similar results utilizing USDA-ERS food availability data. 
Figure 6. The Capacity To Support Food Requirements Based on the DGA

The regional capacity to support food requirements under federal food guidelines in three foodshed regions. Zero in the graphs represents $100 \%$ of food requirements.

\section{(a) Capacity To Feed Philadelphia: Capacity of the Different Foodsheds To Support the Population of Philadelphia (see table 9)}

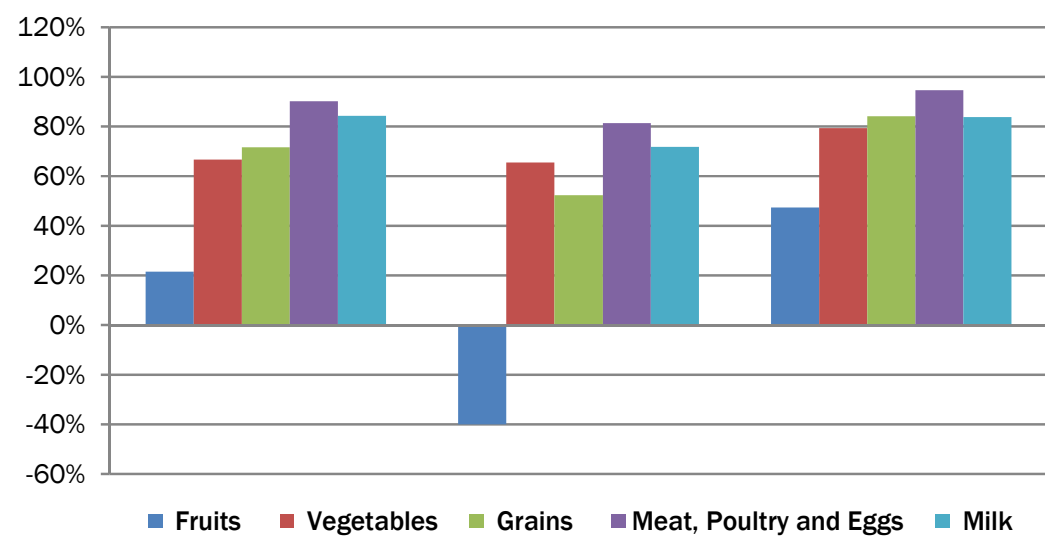

(b) Foodshed Self-Sufficiency: Capacity of the Different Foodsheds To Self-Support Their Entire Populations (see table 10)

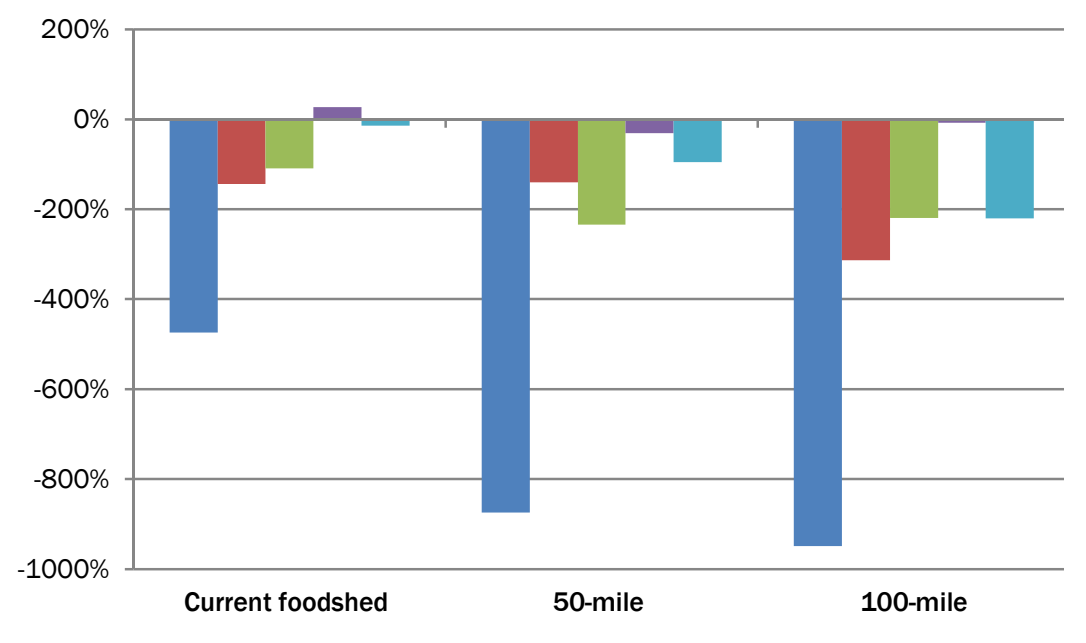

\section{Discussion}

Supplying Philadelphia's Dietary Requirements

Studying the extent to which food production can supply the dietary requirements of the population of the city of Philadelphia, we analyzed data for current agricultural production under the different definitions of foodshed regions for Philadelphia and compared it to the DGA requirements and current food consumption of four food groups: fruits, vegetables, meat, and dairy. The results indicate that the amount of food produced in most of the defined foodshed regions easily meets the dietary requirements of Philadelphia, using both the DGA and the ERS food availability dataset. An exception is the fruit group, in which a shortage of $40 \%$ (by the DGA) and 18\% (by the ERS dataset) occurred in the 50 mile foodshed. The reason for this shortage is that some of the most intensive fruit-producing counties that traditionally supply fruit to Philadelphia and the region, such as Adams and York counties in Pennsylvania, fall outside the 50-mile foodshed, but are included in all other foodshed regions. The 50-mile foodshed also lacks feed grain for animals by $4 \%$. All regions except for the 50-mile foodshed produced grain for animal feed in sufficient quantity to supply Philadelphia's meat, poultry, and dairy requirements.

In the100-mile foodshed, Philadelphia's consumption represents between 5\% (meat) to 53\% (fruit) 
of total production. In the 50-mile foodshed, Philadelphia's population requires $19 \%$ of the region's meat production, while its demand for fruits is underserved by $40 \%$. On average, for all the food groups, Philadelphia's food requirements represent between $21 \%$ (in the case of the largest region, including all counties) and $51 \%$ (in the case of the 50-mile foodshed) of total regional production.

One of the interesting issues that emerge from this analysis is the difference in the results when considering the DGA and current consumption according to the food availability database. While the general trend is similar, differences appear in the total shortage or surplus for different food groups. For example, for vegetables and milk, a larger surplus occurs using the ERS food availability data, and in the case of meat, a larger surplus appears when using the DGA. Analyzing the difference in the results for DGA and current food consumption reveals that a change from current consumption to federal guidelines would result in a larger consumption of the regions' fruits, vegetables, and dairy and a lower consumption of the regions' grains, meat, poultry, and eggs. Together with the literature arguing that dietary choices have a significant impact on the resources and energy required for food production and that meat-intensive diets requires more resources in terms of land and energy (Gerbens-Leenes, 2006; Peters et al., 2007; Pimentel \& Pimentel, 2008; Risku-Norja et al., 2008), these results suggest that requirements.

\section{Figure 7. Capacity To Support Food Requirements Based on Current Food Consumption}

The regional capacity to support food requirements under USDA ERS food availability data in three foodshed regions. Zero in the graphs represents $100 \%$ of food

\section{(a) Capacity To Feed Philadelphia: Capacity of the Different Regions To Support the Population of Philadelphia}

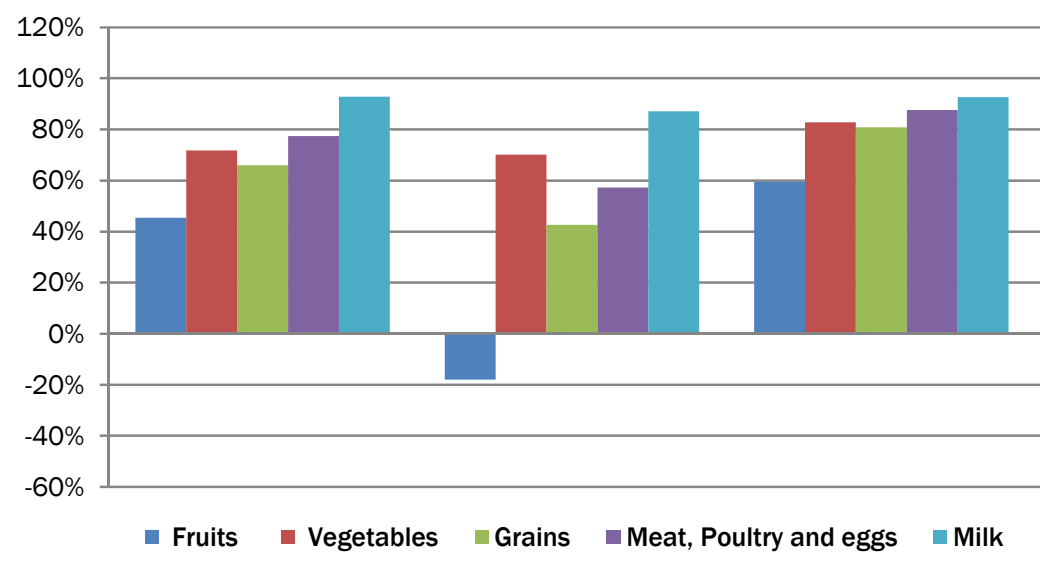

(b) Foodshed Self-Sufficiency: Capacity of the Different Regions To Self-Support Their Entire Populations

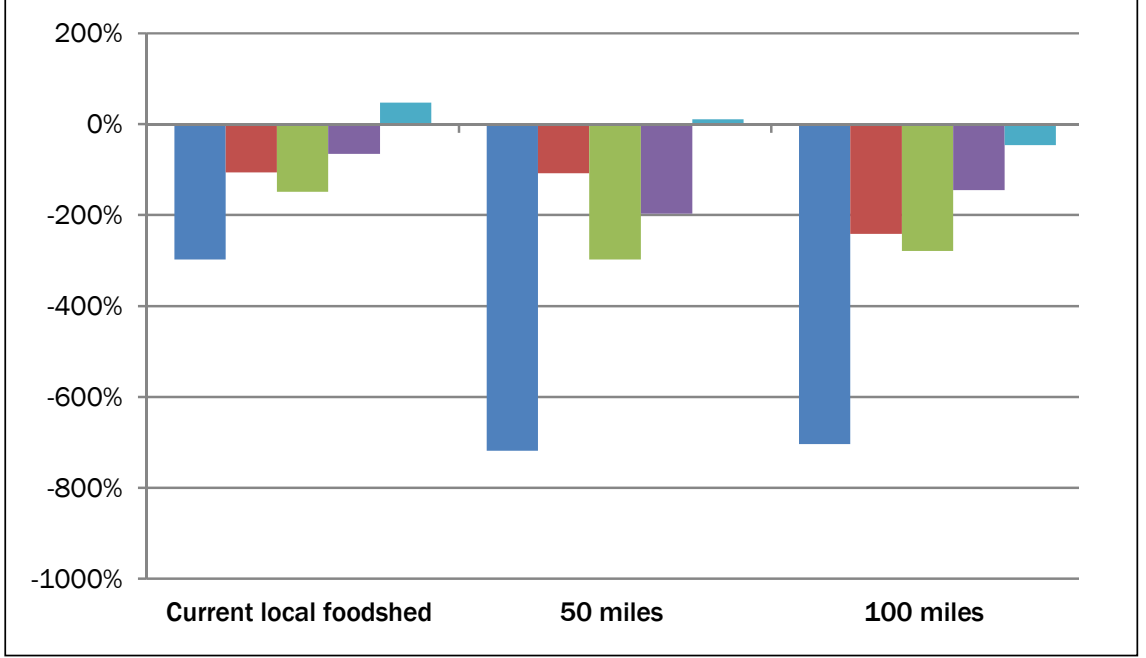


Figure 8. The Regional Capacity To Support Animal Grain Feed Production for Consumption of Meat, Poultry, Eggs, and Milk by the Philadelphia Population and the Entire Population of Each Defined Foodshed Region

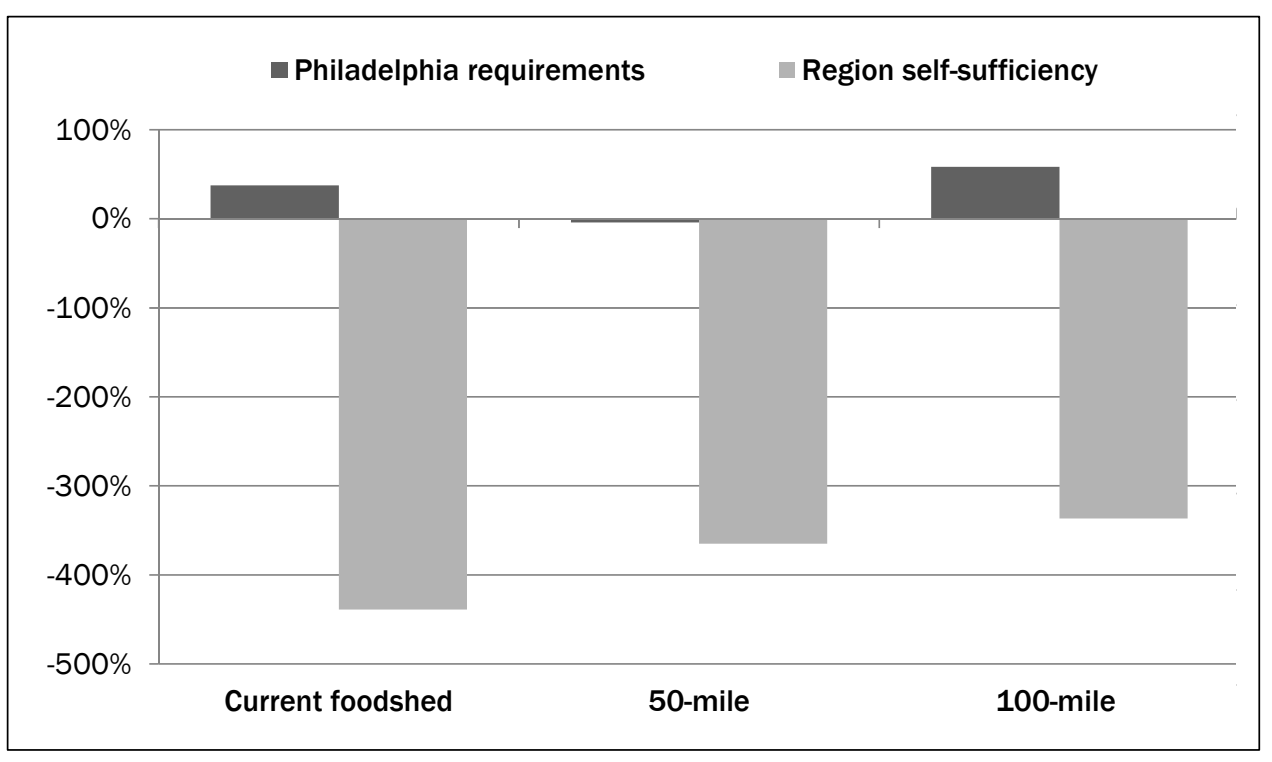

compared this to the food production of the corresponding regions (as represented in figures $6-\mathrm{b}$ and 7-b). The results indicate that in all the foodshed regions, the quantity of food grown is not sufficient to support the population of those regions. Fruits and vegetables are in large deficit in all the foodshed regions, using both dietary requirements evaluation methods. The largest deficit is in fruits, which is production means that if the population were to rely on the region's produce, only a limited diet currently would be possible. In the case of vegetables and grains, a shift toward a more diverse representation of crops in agriculture practices is possible since the region's the soil and weather conditions enable the production of most grains and vegetables. In the case of fruits, the choice is more limited. Some fruits, such as citrus and tropical varieties, are obviously not suitable for the study region, and thus without imports, these varieties would be completely absent from the population's diet. This point is one important weakness of any analysis that generalizes land use and production potential and indeed underscores the fact that fundamental changes in land use, agricultural decisions, and consumption patterns are necessary for even a partial localization and regionalization of the Philadelphia region food system.

\section{Foodsheds and Regional Self-sufficiency}

We performed a second set of food requirements and food consumption calculations to include the total population of the foodshed regions and then almost 950\% short in the two largest foodsheds. Vegetables exhibit shortages up to triple the amount available. In the case of meat and poultry, consumption based on dietary guidelines results in a close match between production and requirements. However, for current consumption as represented by ERS food availability, a shortage exists in all foodshed regions. Using current food consumption trends, milk is produced in a sufficient quantity to meet the consumption demand in the current foodshed as well as the 50-mile foodshed. None of the foodshed regions produces enough feed grains to support meat and dairy consumption fully.

On average, for all the food groups, the shortage in food production ranged between $143 \%$ in the current local foodshed to $342 \%$ in the 100 -mile foodshed region. The steepest shortages were for fruits, followed by vegetables at $420 \%$. Thus, supplying the entire population of these regions with an adequate diet based on both the DGA and current consumption patterns would require enlarging the foodshed or including food supplies imported from other, more distant regions. 
We compared the results of this study with a calculation using an average number of acres per person required to provide an average diet that meets the DGA (adjusted from Peters et al., 2007), and found similarities in the general trends of the data, although the total deficiencies in the different regions vary greatly (up to $50 \%$ in the case of the 50-mile region). A comparison of the results for all the foodshed regions, for the Philadelphia population, and for the self-sufficiency of each region is presented in Figure 9.

\section{Overlapping Foodsheds in Urbanized Regions}

The results of this regional foodshed analysis exemplify the importance of the issue illustrated in figure 1, that when discussing foodsheds as selfcontaining regions, issues arise of overlapping populations and competition for food resources. The notion of a foodshed implies directionality in the flow of food from agricultural areas with lower population concentrations to more densely populated areas and large cities. The highly concentrated populations in metropolitan areas along the East Coast, which include Philadelphia, New York, Baltimore, and Washington, D.C., means that the foodsheds for these cities are bound to overlap. Philadelphia is located at the center of the most densely populated region in the United States. Its 100-mile foodshed contains about $10 \%$ of the total U.S. population and overlaps with foodsheds for New York City and Baltimore. The 50-mile foodshed does not include any of these metropolitan areas, but still is home to over 11 million people living in smaller cities around Philadelphia, such as Camden, New Jersey, and Wilmington, Delaware.

Nonetheless, as the definition of foodshed widens, the overlap declines. While the foodshed of Camden may be very similar to that of Philadelphia, ${ }^{1}$ New York City can reach to upstate New York counties and even some New England counties for dairy products and fruit and into New Jersey for vegetables. A central question this situation raises is the likelihood of food that is produced within the foodshed region, even in a

\footnotetext{
1 This definition only pertains to arbitrarily defined foodsheds of specific radii. As we show elsewhere (Kremer et al., forthcoming), there are administrative, political, and cultural issues that affect the shape of a foodshed. In the case of Camden, NJ, we can expect more food coming to that city from the agricultural counties of New Jersey than we see in Philadelphia's local food system. Thus, although the cities are physically adjacent in terms of their locations and are separated only by the Delaware River and the state line, they develop and experience different local foodshed structures.
} 
localized food system, reaching Philadelphia rather than other population centers in the region. It was beyond the scope of this study to measure these overlaps and estimate the extent of the resulting competition over local food resources between these cities and their economic implications. Still, it is clearly an issue for participants in the local food system in Philadelphia, who often suggest that the city is disadvantaged by its proximity to the more lucrative New York City market (DVRPC, 2010; Kremer et al., forthcoming). More research is thus needed to address these issues.

\section{Conclusion}

In this study we analyzed the statistical data on land use and agricultural production and compared that data to current dietary requirements as represented in consumption practices and federal dietary guidelines, to evaluate the potential for a semi-open regional food system that can satisfy the dietary requirements of the city of Philadelphia. In addition, we evaluated the ability of three defined foodshed regions around Philadelphia to produce enough food to support their entire populations. The results show that while the agricultural hinterland in most of the defined foodshed regions may produce enough food to satisfy the dietary requirements of the city, issues of overlapping foodsheds and competition over local food resources may complicate the development of a localized food system around major metropolitan areas. Finally, we would like to point out the effectiveness of the current local foodshed. The local foodshed is defined as the area that includes all counties currently supplying local food to the city's farmers' markets, retail markets, and institutions. In all, 37 counties are included in the current local foodshed (in comparison to the 69 counties included in the 100-mile foodshed), which is not geographically continuous. Nonetheless, this foodshed is almost as effective as larger foodshed regions in addressing the dietary requirements of the city's population. Since this is a self-organized region, ${ }^{2}$ namely a region defined by the self-

2 As explained elsewhere (Kremer, 2011), farmers selling in farmers' markets are not limited by travel distance, but do have organization of the current local food system, it is possible that the city attracts more agriculture counties and creates a spatial structure that can be interpreted as a foodshed that best fits its needs. This finding indicates that there is still much to learn about emerging local food systems, and that their patterns of development can offer considerable insight into the future of food system localization and regionalization.

While this study begins the discussion about the capacity and potential of food system localization in major metropolitan regions, much research is still needed. Major areas for further research identified in this paper include:

- Addressing demographic and socioeconomic characteristics and their interaction with market forces that contribute to actual food pathways;

- Addressing the question of overlapping foodsheds; and

- Incorporating in the analysis the impact of variation in dietary choices on foodshed capacity.

\section{References}

Berry, W. (1990). What are people for? San Francisco: North Point Press.

Clancy, K., \& Ruhf, K. (2010). Is local enough? Some arguments for regional food systems. Choices: The Magazine of Food, Farm, and Resource Issues, 25(1). Retrieved from http://www.choicesmagazine.org/ magazine $/$ article.php?article $=114$

Delaware Valley Regional Planning Commission (DVRPC). (2010). Greater Philadelphia food systems study. Philadelphia: Author.

Gerbens-Leenes, P. W. (2006). Natural resource use for food: Land, water and energy in production and consumption systems (Unpublished doctoral dissertation). University of Groningen, the Netherlands.

to see traveling to the city to sell their products as economically cost efficient. 
Giombolini, K. J., Chambers, K. J., Schlegel, S. A., \& Dunne, J. B. (2011). Testing the local reality: Does the Willamette Valley growing region produce enough to meet the needs of the local population? A comparison of agriculture production and recommended dietary requirements. Agriculture and Human V alues, 28(2), 247-262.

Kantor, L. S. (1998). A dietary assessment of the U.S. food supply: Comparing per capita food consumption with food guide pyramid serving recommendations (Agricultural Economic Report No. 772). Washington, D.C.: Food and Rural Economics Division, Economic Research Service, U.S. Department of Agriculture.

Kantor, L. S. (1999). A comparison of the U.S. food supply with the food guide pyramid recommendations. In E. Frazao (Ed.), America's eating habits: Changes and consequences (Agriculture Information Bulletin No. AIB750). Washington, D.C.: Economic Research Service, U.S. Department of Agriculture.

Kremer, P. (2011). Local food systems as a strategy for sustainability: Analysis of a scale dependent sustainable urban food system A case study in Philadelphia (Doctoral dissertation). Retrieved from ProQuest Dissertations and Theses (publication number 3465799).

Kremer, P., \& DeLiberty, T. L. (2011). Local food practices and growing potential: Mapping the case of Philadelphia. Applied Geography, 31(4), 1252-1261. http://dx.doi.org/10.1016/j.apgeog.2011.01.007

Kremer, P., DeLiberty, T. L., \& Schreuder, Y. (in press). Defining local food systems. In N. Reid, J. D. Gatrell \& P. Ross (Eds.), Local food systems in old industrial regions: Spatial context and local practices. Surrey, UK: Ashgate.

Martinez, S. W., Hand, M., Da Pra, M., Pollack, S., Ralston, K., Smith, T.,...Newman, C. (2010). Local food systems: Concepts, impacts, and issues (ERS Report No. 97). Washington, D.C.: U.S. Department of Agriculture, Economic Research Service.

Peters, C. J., Bills, N. L., Lembo, A. J., Wilkins, J. L., \& Fick, G. W. (2009). Mapping potential foodsheds in New York State: A spatial model for evaluating the capacity to localize food production. Renewable Agriculture and Food Systems, 24(1), 72-84. http://dx.doi.org/10.1017/S1742170508002457
Peters, C. J., Fick, G. W., \& Wilkins, J. L. (2003). Cultivating better nutrition: Can the food pyramid help translate dietary recommendations into agricultural goals? Agronomy Journal, 95(6), 1424-1431. http://dx.doi.org/10.2134/agronj2003.1424

Peters, C. J., Wilkins, J. L., \& Fick, G. W. (2007). Testing a complete-diet model for estimating the land resource requirements of food consumption and agricultural carrying capacity: The New York State example. Renewable Agriculture and Food Systems, 22(2), 145-153.

Pimentel, D., \& Pimentel, M. (2008). Food, energy, and society (Third ed.). Boca Raton, FL: CRC Press.

Risku-Norja, H., Ketomaki, H., Hietala, R., Helenius, J., \& Virtanen, H. (2008). Localisation of primary food production in Finland: Production potential and environmental impacts of food consumption patterns. Agricultural and Food Science, 17(2), 127-145.

Smith, A., \& MacKinnon, J. B. (2008). The 100-Mile diet: A year of local eating. Melbourne: Text Publishing Company.

U.S. Census Bureau. (2000). American Factfinder: Census 2000 Summary File 1. Retrieved from http://factfinder.census.gov/servlet/DatasetMainP ageServlet? ds name=DEC 2000 SF1 U\& progr am=DEC\& lang=en

U.S. Department of Agriculture (USDA). (2007). Census of Agriculture. Retrieved from http://www.agcensus.usda.gov/Publications/ 2007/index.asp

U.S. Department of Agriculture-Economic Research Service (USDA-ERS). (2009a). Fruit and tree nut yearbook. Retrieved from http://usda.mannlib.cornell.edu/MannUsda/view StaticPage.do?url=http://usda.mannlib.cornell.edu /usda/ers/./89022/2009/index.html

USDA-ERS. (2009b). Vegetables and melons yearbook for 2009. Retrieved from http://usda.mannlib.cornell.edu/MannUsda/view DocumentInfo.do?documentID=1212

USDA-ERS. (n.d.). Food availability (per capita) data system. Retrieved from http://www.ers.usda.gov/ Data/FoodConsumption

U.S. Department of Agriculture-Food \& Nutrition Service (USDA-FNS). (2009). Dietary guidance. Retrieved from http://fnic.nal.usda.gov/nal display/index.php?info center $=4 \&$ tax level $=3 \& \operatorname{tax}$ subject $=256 \&$ topic $\mathrm{id}=1342 \&$ level $3 \mathrm{id}=5140$ 
U.S. Department of Agriculture-National Agricultural Statistics Service (USDA-NASS). (2007). Census of Agriculture: 2007 State-County Data, Dataquery Desktop Tool. Washington, D.C.: Author.

USDA-NASS. (2009a). Livestock slaughter: 2009 summary. Washington, D.C.: Author.

USDA-NASS. (2009b). Poultry - Production and Value: 2009 Summary. Washington, D.C.: U.S. Department of Agriculture.

U.S. Department of Agriculture and U.S. Department of Health \& Human Services (USDA \& USDHHS).
(2010). Dietary guidelines for Americans, 2010 (7th ed.). Washington, D.C.: Author.

Young, C. E., \& Kantor, L. S. (1999). Moving toward the Food Guide Pyramid: Implications for U.S. agriculture. In E. Frazao (Ed.), America's eating habits: Changes and consequences (Agriculture Information Bulletin No. AIB750). Washington, D.C.: U.S. Department of Agriculture, Economic Research Service. 
Journal of Agriculture, Food Systems, and Community Development ISSN: 2152-0801 online www.AgDevJournal.com 